\title{
Distribution and retention of Sabellaria alveolata larvae (Polychaeta: Sabellariidae) in the Bay of Mont-Saint-Michel, France
}

\author{
Stanislas Dubois ${ }^{1,3, *}$, Thierry Comtet $^{2}{ }^{2}$ Christian Retière $^{1}$, Eric Thiébaut ${ }^{2}$ \\ ${ }^{1}$ UMR 5178 BOME (MNHN, CNRS, UPMC)—Muséum National d'Histoire Naturelle, Département Milieux et Peuplements \\ Aquatiques, Station Marine de Dinard, BP 70134, 35801 Dinard cedex, France \\ ${ }^{2}$ UMR 7144 CNRS - Université Pierre et Marie Curie, Station Biologique, BP 74, 29682 Roscoff cedex, France \\ ${ }^{3}$ Present address: IFREMER, Centre de Brest, Laboratoire DYNECO Ecologie Benthique, Technopole de Brest-Iroise, \\ BP 70, 29280 Plouzané, France
}

\begin{abstract}
The gregarious polychaete Sabellaria alveolata is an important foundation species whose reef structures add topographic complexity and high levels of biodiversity in sandflats. In the Bay of Mont-Saint-Michel, France, $S$. alveolata reefs are considered the largest reef formations in Europe and are increasingly endangered by anthropogenic pressure. In order to understand the role of larval transport on the resilience capacity of these biogenic reefs, multiple complementary approaches were carried out within the bay in 2002 to study horizontal and vertical distribution of $S$. alveolata larvae and assess larval dispersal processes. Plankton samples collected twice a month from March to October showed an extended period of larval occurrence, from the end of April to October, with 2 peaks of high abundance. The main spawning period occurred early in May, and a smaller peak occurred in September. Mean planktonic lifetime has been calculated to be between 4 and $10 \mathrm{wk}$. At large scale, larval distribution was patchy and the maximal abundance could reach about 28000 larvae $\mathrm{m}^{-2}$. Larval densities were strongly correlated with physico-chemical parameters so that larvae were more abundant in a warmer and less saline coastal water mass characterised by a higher concentration in chlorophyll $a$. The presence of a large anticyclonic gyre in the bay seemed to play a significant role in controlling larval dispersal by concentrating larvae within the bay. At 1 station in the bay, short-term variations of larval abundances in the water column appeared to be regulated by the tidal cycle, as larvae were more abundant at the end of ebb tide, confirming the very coastal distribution of larvae. Furthermore, S. alveolata larvae tended to migrate closer to the surface during flood and near the bottom during ebb, promoting a net landward transport of larvae. Despite a long larval lifespan, our results indicate that tidal residual currents, especially a coastal gyre, and tidal vertical migration may favour larval retention within the bay.
\end{abstract}

KEY WORDS: Sabellaria alveolata $\cdot$ Polychaetes $\cdot$ Larval dispersal $\cdot$ Vertical migration $\cdot$ Planktonic lifetime $\cdot$ English Channel $\cdot$ Bay of Mont-Saint-Michel

Resale or republication not permitted without written consent of the publisher

\section{INTRODUCTION}

In temperate regions, marine invertebrate species, including polychaetes (e.g. sabellariids, serpulids) and bivalves (e.g. mytilids, ostreids), build biogenic reefs, which are aggregations composed of the reef-building organisms with their tubes or shells more or less mixed with sediments (Holt et al. 1998). These reefs provide a unique substratum from the surrounding habitat, with considerably more available hard surfaces and crevices on which specific benthic communities may develop. Even if some reef-building organisms may be common and widespread, biogenic reefs generally form biotopes of great importance to biological conservation, as they can: (1) provide habitat for other species, (2) exhibit particularly high species richness, (3) 
play an efficient role in the functioning of the ecosystems and (4) have a high aesthetic or recreational value. Thus, reefs are listed under Annex I of the EC Habitats Directive (Council Directive EEC/92/43 on the Conservation of Natural Habitats and of Wild Fauna and Flora) as a marine habitat to be protected by the designation 'Special Areas of Conservation'.

Among polychaetes of the family Sabellariidae, the honeycomb worm Sabellaria alveolata is the most common reef-building species along European Atlantic coasts, occurring on intertidal shores from the Solway Firth (West Scotland) to the south of Morocco (Cunningham et al. 1984). In the Bay of Mont-Saint-Michel, $S$. alveolata reefs create irregularly shaped, patchy banks that cover approximately 250 ha, with densities of up to 60000 ind. $\mathrm{m}^{-2}$ and are considered the largest reef formations on European coasts (Dubois et al. 2002 and references therein). These reef structures add topographic complexity and exhibit high levels of biodiversity (Dubois et al. 2002, 2006). As tube-builders, they can alter sedimentary processes (Mathieu 1967), and as suspension feeders also play a significant role within the trophic web (Dubois et al. 2003). Sabellarian reefs are a highly dynamic habitat subject to numerous perturbations including natural events (e.g. cold winters, storms) and anthropogenic disturbances (e.g. physical damage, aquaculture) (Dubois et al. 2002, 2006). In the Bay of Mont-Saint-Michel, recent studies emphasised that anthropogenic threats such as oyster farming, fishing and trampling alter $S$. alveolata population structure, causing a reduction in new recruit densities that may induce significant damage to the reef structure over time, as well as to the associated fauna (Dubois et al. 2006).

The ability to recover from anthropogenic disturbances depends on the recolonisation of damaged Sabellaria alveolata reefs. It is thus critical to obtain accurate data on both spawning seasons and larval dispersal. Conflicting results between spawning season and larval lifetime can be found in the literature (e.g. Wilson 1968b, 1970, 1971), and none of these data refer to the Mont-Saint-Michel reefs, the largest known reefs. Like the majority of coastal benthic invertebrates, $S$. alveolata exhibits a complex life cycle that includes a planktonic larval stage and 2 bottomdwelling juvenile and adult stages (Cazaux 1964). It has a mean lifespan of 4 to $5 \mathrm{yr}$, although some individuals can live to be 8 to $10 \mathrm{yr}$ old (Wilson 1971). It is a gonochoric species, with reproductive activity beginning during the first year of the animal's life. While Wilson (1971) reported a short spawning period in July in North Cornwall, Gruet \& Lassus (1983) indicated 2 long spawning periods for a population along the French Atlantic coast (Noirmoutier Island): March to April and June to September. From laboratory cultures and field observations, Wilson (1968b, 1970, 1971) reported a highly variable rate of larval development, with a fertilisation-to-metamorphosis time-i.e. planktonic lifetime-ranging from $6 \mathrm{wk}$ to $8.5 \mathrm{mo}$, partly in relation to the quantity and quality of food. Moreover, in the Bassin d'Arcachon (French Atlantic coast), $S$. alveolata larvae with a larval lifespan estimated to be about 12 wk were reported in plankton samples mainly from October to March (Cazaux 1970). Otherwise, $S$. alveolata larvae exhibit active habitat selection (i.e. larvae ready to settle are attracted by adult and juvenile tubes of its own species) and are able to delay metamorphosis if proper environment for settlement is not encountered (Wilson 1968a). Although understanding the dispersal phase of such a species is crucial to predict changes in population structure and dynamics and to properly manage coastal habitats in response to anthropogenic disturbances (Eckman 1996, Kinlan et al. 2005), data concerning S. alveolata larval transport are still lacking.

To better understand the resilience capacity of the endangered biological inheritance represented by Sabellaria alveolata reefs in the Bay of Mont-SaintMichel and to propose conservation strategies, the objectives of the present study were to describe the spatial and temporal distribution of $S$. alveolata larvae in the bay. Using complementary investigative approaches, the main questions we addressed were: (1) What is the main period of occurrence of larvae in the water column and the in situ larval lifespan? (2) What is the relative influence of biological factors and hydrodynamic processes on larval transport? And (3) How can larval dispersal explain the local recruitment and the persistence of this species in a highly hydrodynamic environment?

\section{MATERIALS AND METHODS}

Study area. The Bay of Mont-Saint-Michel is a coastal embayment in the southeast of the NormanBreton Gulf (western English Channel) and covers an area of ca. $500 \mathrm{~km}^{2}$ from Cancale to Granville (Fig. 1). It is a macrotidal system with a tidal range reaching $16 \mathrm{~m}$ during spring tide and tidal flats covering $240 \mathrm{~km}^{2}$. Maximal instantaneous tidal currents vary from $0.5 \mathrm{~m} \mathrm{~s}^{-1}$ in the eastern part of the bay to $0.8 \mathrm{~m} \mathrm{~s}^{-1}$ in the central and western part, of the bay, where the currents alternate. Freshwater inputs are from 3 small rivers (i.e. the Sée River, the Sélune River and the Couesnon River) in the eastern part of the bay and do not exceed $25 \mathrm{~m}^{3} \mathrm{~s}^{-1}$, so that the water column is well mixed in most of the bay. Residual circulation depends mainly on tides and is characterised by an anticyclonic gyre off Cancale, a large cyclonic gyre around the 


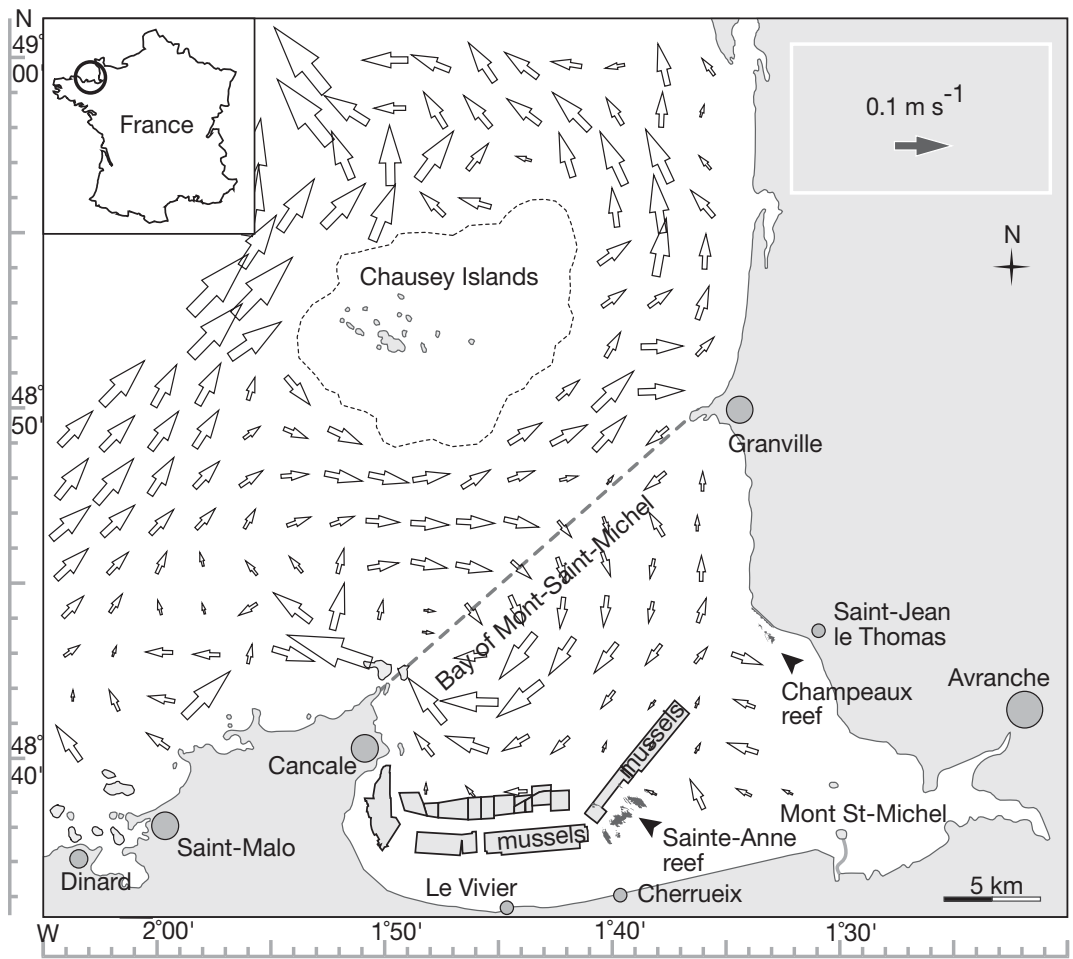

Fig. 1. Location of the study area and schematic representation of tidal residual velocity fields in the Bay of Mont-Saint-Michel (re-drawn from Garreau 1993) squares labelled $77,78,79$ and 80 in Fig. 2). Stations were chosen according to the location of the $2 S$. alveolata reefs and the limits of the bay. From March 2002 to October 2002, the 4 stations were sampled every $15 \mathrm{~d}$ during neap tide. The samples were collected during the same tidal cycle for the 4 stations around high tide $( \pm 1 \mathrm{~h})$ to ensure that the same water mass was not sampled twice. Larvae were collected with a WP2 plankton net (0.25 $\mathrm{m}^{2}$ opening and $80 \mu \mathrm{m}$ mesh size). At each station, the WP2 net was towed vertically from bottom to surface. The volume of water filtered through the net was estimated using a Tsurumi-Seiki Kurusawa (TSK) flow meter. All samples were preserved in $5 \%$ formalin buffered with sodium borate. Salinity and temperature of surface water were measured with an electronic conductimeter WTW Model LF196. In addition, samples of surface water were collected to assess chlorophyll a (chl a) and phaeopigment con-
Chausey Islands and a reduced drift of water masses to the north along the coast of Normandy (Fig. 1). The gyre off Cancale can be partly disrupted when wind velocity exceeds $8 \mathrm{~m} \mathrm{~s}^{-1}$ (Salomon \& Breton 1993).

In the intertidal zone, 2 main Sabellaria alveolata reefs are present: 1 in the central part of the bay (i.e. Ste-Anne reef, $48^{\circ} 35^{\prime} \mathrm{N}, 01^{\circ} 40^{\prime} \mathrm{W}$ ), with a surface area of ca. $2.25 \mathrm{~km}^{2}$, and 1 in the eastern part of the bay (i.e. Champeaux reef, $48^{\circ} 44^{\prime} \mathrm{N}, 01^{\circ} 33^{\prime} \mathrm{W}$ ), with a surface area of ca. $0.3 \mathrm{~km}^{2}$ (Fig. 1). Within the western bay, the lower part of the intertidal zone sustains important shellfish culture stocks (12000 t of mussels and $6000 \mathrm{t}$ of oysters).

Sampling. The distribution of Sabellaria alveolata larvae at different scales in space and time was studied by combining 3 sampling strategies:

Seasonal occurrence: To determine the occurrence period and planktonic lifetime of Sabellaria alveolata larvae, plankton samples were obtained at 4 fixed stations within the bay (i.e. the

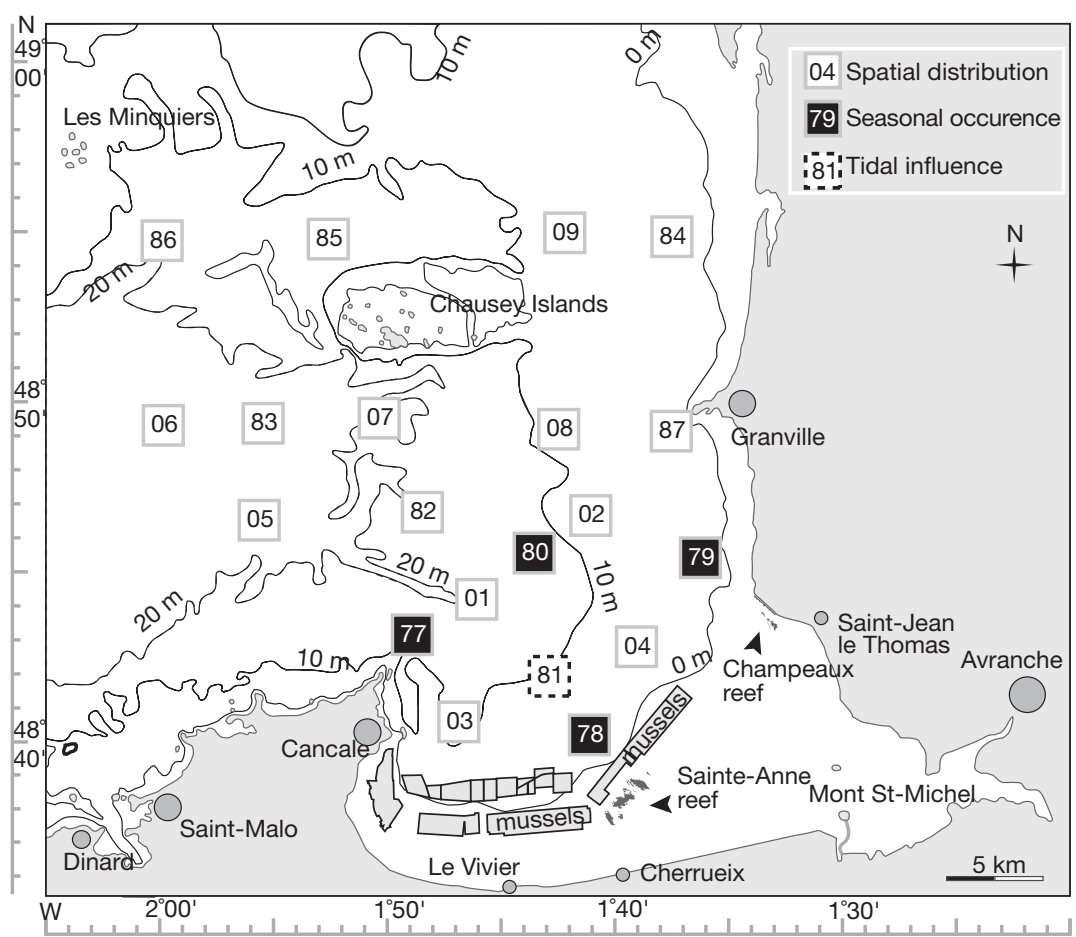

Fig. 2. Location of the sampling stations in the Bay of Mont-Saint-Michel corresponding to the 3 sampling strategies, i.e. determination of seasonal occurrence (4 fixed stations: Stns 77, 78, 79 and 80), of large-scale spatial distribution (all 20 stations) and of tidal influence (Stn 81) 
centrations: 1.51 was filtered through Whatman GF/F filters and kept at $-20^{\circ} \mathrm{C}$ until analysis. Pigment concentrations were measured by the fluorometric method of Lorenzen (1966). Two sampling dates were cancelled in mid-May and mid-June because of bad weather, except for Stn 78, where only 1 sample was missing in mid-May.

Spatial distribution: To describe the maximal extent of the larval patch over a large scale, a network of 20 stations, including Stns 77 to 80, was sampled during 2 cruises: 15 to 17 July 2002 and 20 to 22 July 2002 (white and black squares in Fig. 2). Stations were equally distributed from the Sabellaria alveolata reefs to the open sea behind the Chausey Islands. The sampling strategy was the same for the 2 cruises. Larvae were collected with a WP2 plankton net (3 replicates) of $80 \mu \mathrm{m}$ mesh size. The water column was characterised by vertical profiles of temperature, salinity and chl a using a CTD recorder (Seabird SBE 911) coupled with a Chelsea fluorimeter (wavelength excitation = $685 \mathrm{~nm}$; accuracy $= \pm 0.02 \mu \mathrm{g} \mathrm{l}^{-1}$ ).

Tidal influence: To identify short-term variations in tidal transport and vertical distribution of larvae, zooplankton was sampled over a $24 \mathrm{~h}$ time series from 18 (07:00 h) to 19 July 2002 (07:00 h) at Stn 81 (Fig. 2). Samples were collected from the whole water column, at 3 depths ( $2 \mathrm{~m}$ below the surface, $2 \mathrm{~m}$ above the bottom and in the middle of the water column) using a volumetric PCM Moineau pump, delivering $3201 \mathrm{~min}^{-1}$. Samples were collected every $2 \mathrm{~h}$ for $10 \mathrm{~min}$ at each depth, and each $3.2 \mathrm{~m}^{3}$ of seawater was filtered through a $80 \mu \mathrm{m}$ mesh screen. The structure of the water column was also characterised by vertical profiles of temperature, salinity and chl a.

Sabellaria alveolata larval stages. S. alveolata larvae were sorted, identified according to Wilson (1968b) and Cazaux (1964), and counted using a dissecting microscope. For each sample, a preliminary observation was performed to estimate larval densities. When larval density was low, the whole sample was counted. In the case of high larval density, sub-samples were taken and larvae were counted using Frontier's (1969, 1972) method: the sample was brought to $200 \mathrm{ml}$ with filtered seawater, homogenised, and a 1/10 aliquot was pipetted into a reticulate Dolfuss receptacle composed of 200 distinct cells. Assuming that planktonic organisms are randomly distributed in the receptacle, approximately 100 larvae were counted per sample to obtain a good estimate of larval abundances (Frontier 1972). Results were expressed as number of larvae $\mathrm{m}^{-3}$ or number of larvae $\mathrm{m}^{-2}$.

From the larval development description of Sabellaria alveolata (Cazaux 1964), 4 planktonic stages were distinguished. Each stage corresponds to a significant morphological evolution of the larva:
- Trochophore larva (Stage 1), between 90 and $120 \mu \mathrm{m}$ long, without any segmentation;

- Young metatrochophore larva (Stage 2), between 120 and $350 \mu \mathrm{m}$, with apparition of the first abdominal segment and ocellus present;

- Old metatrochophore larva (Stage 3), between 350 and $500 \mu \mathrm{m}$, and characterised by a darker pigmentation, an increase in abdominal segment number and especially the formation of 2 tentacular buds;

- Erpochete larva (Stage 4), ready for settlement, longer than $500 \mu \mathrm{m}$, and characterised by larger abdominal segments, densification of pigmentation, lengthening of tentacular palps and formation of future palea of the worm.

Data analysis. Spatial and spatio-temporal variations in the physico-chemical parameters were depicted with contour plots using Golden Graphics System software (SURFER V 8.0). Densities of larvae dealing with the spatial extent of the larval patch were reported in surface area units rather than volume units in order to avoid any bias due to a potential stratification in vertical larval distribution and to the spatial variations of the water column depth. Relationships between larval densities and physico-chemical parameters were measured for each cruise using Spearman's coefficient of rank correlation using means for the water column.

To detect any movement of Sabellaria alveolata larvae within the water column in relation to tidal and diel cycles, the centre of mass of the larval vertical distribution was calculated for a relative depth (Fortier \& Leggett 1983):

$$
\mathrm{RZCM}=\frac{\sum\left(C_{i, z} \times D_{z}\right)}{\sum C_{i, z}}
$$

where RZCM is the relative centre of mass, $C_{i, z}$ is the larval concentration at $z$ depth and for the $i$ th time interval, and $D_{z}$ is the relative depth as $D_{z}=0$ for the surface, $D_{z}=0.5$ for the middle of the water column and $D_{z}=1$ for the bottom.

To measure larval aggregation, the coefficient of variation $(\mathrm{CV}=$ standard deviation/mean $\times 100)$ of larval concentration was used. A high $\mathrm{CV}$ indicated a strong aggregation of larvae, while a low CV indicated a more homogeneous distribution of larvae in the water column (Thiébaut et al. 1992).

\section{RESULTS}

\section{Seasonal distribution of Sabellaria alveolata larvae}

Plankton samples collected twice a month from March 2002 to October 2002 showed large variations in larval abundances in time and space (Fig. 3). Although the occurrence period of larvae in samples 

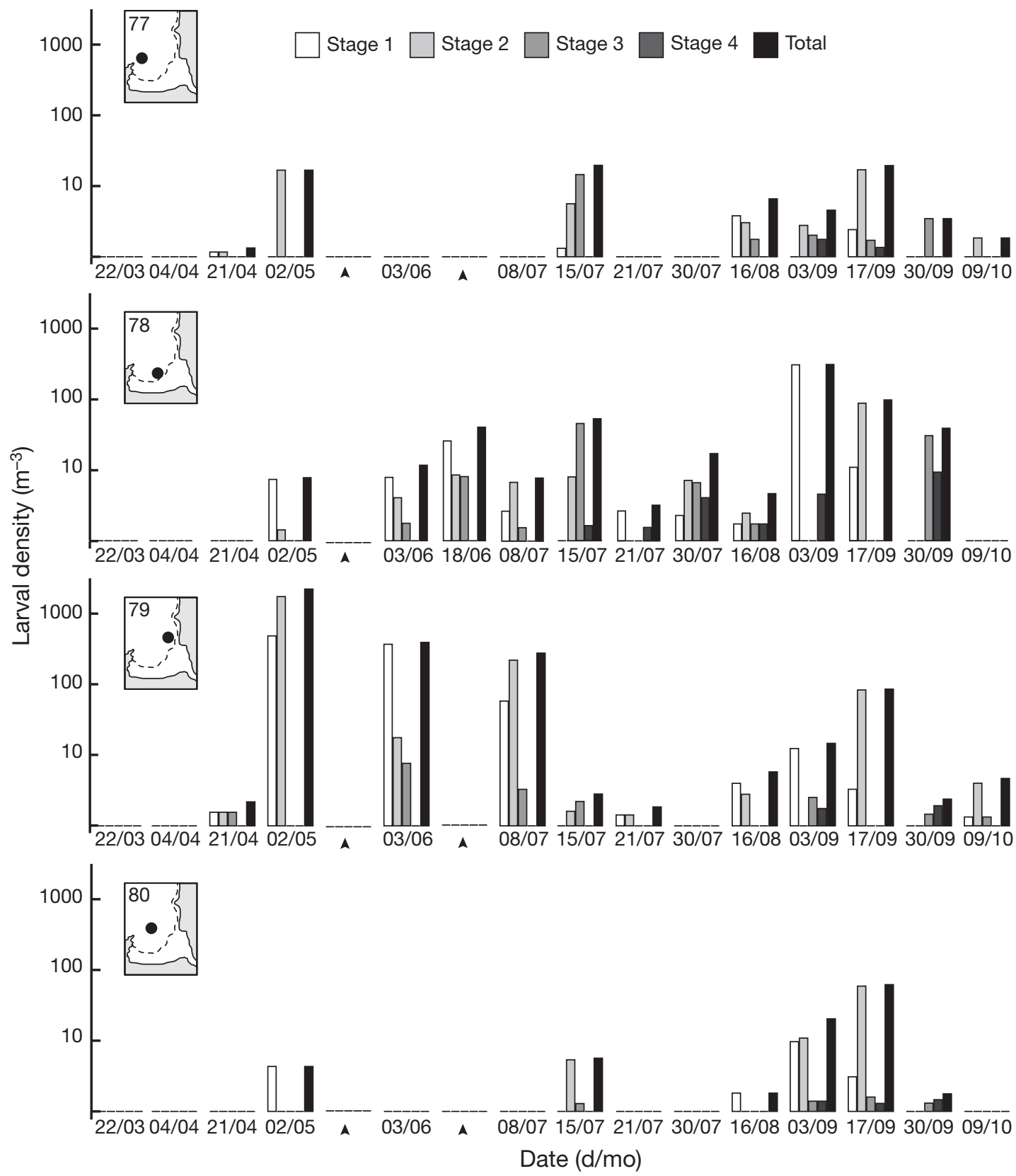

Fig. 3. Sabellaria alveolata. Temporal evolution of larval densities (log transformed) observed in plankton samples collected at 4 fixed stations (Stns 77, 78, 79 and 80) from March to October 2002 in the Bay of Mont-Saint-Michel. Densities are given for the whole population and for the 4 successive planktonic stages. Arrowheads indicate missing dates

ranged from the end of April to October, 2 main periods of high larval densities were observed. Larvae first appeared during April, when water temperature and chl a concentration increased (Fig. 4), and their densities remained high from the beginning of May until mid-July. A second period of increased larval abundance, shorter in terms of duration, was apparent from early September to the end of September or early October, and corresponded also to a second minor increase in chl a concentration. These 2 periods of high larval densities probably correspond to 2 major spawning periods. Nevertheless, the presence of young larvae (i.e. Stage 1) at most sampling dates suggests a poorly seasonally synchronised spawning. Spatially, Stns 78 and 79, situated closer to the Sabellaria alveolata reefs-i.e. Sainte-Anne and Champeaux reefsshowed the highest larval abundances. However, while maximal larval densities (2250 larvae $\mathrm{m}^{-3}$ ) were 

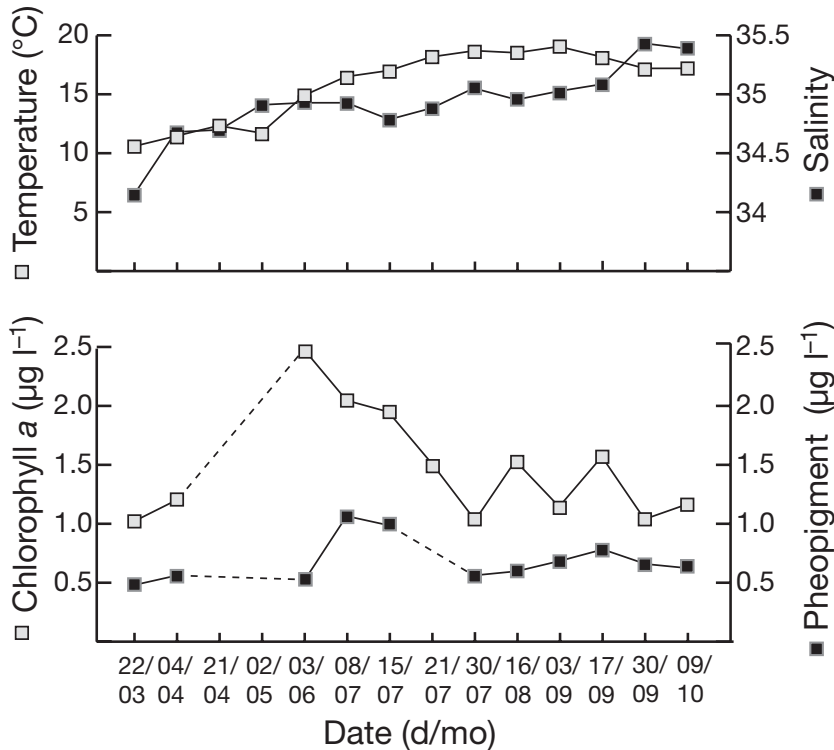

Fig. 4. Temporal evolution of temperature, salinity and concentrations of $\mathrm{chl} a$ and pheopigments in surface water from March to October 2002 in the Bay of Mont-Saint-Michel. Values are mean data collected at 4 stations (Stns 77, 78, 79 and 80). Dashed lines indicate periods with missing samples

reported during the first larval peak in May at Stn 79, maximal densities at Stn 78 (300 larvae $\mathrm{m}^{-3}$ ) were observed during the second larval peak in September.

\section{Large-scale spatial distribution of Sabellaria alveolata larvae}

The large-scale distribution of the larval patch is represented in Fig. 5 for the 2 cruises. Larvae were found at 15 of the 20 stations on the first cruise (15 to 17 July 2002), with densities reaching a maximum of 27680 larvae $\mathrm{m}^{-2}$ at $\mathrm{Stn} 81$, located in the middle of the bay. Highest abundances ( $>1000$ larvae $\mathrm{m}^{-2}$ ) were located within the Bay of Mont-Saint-Michel, but the larval patch showed a northward extension along the western coast of Normandy, with densities reaching a few 10s of larvae $\mathrm{m}^{-2}$. No larvae were found north or west of the Chausey Islands. A similar horizontal distribution pattern was observed on the second cruise (20 to 22 July 2002) despite a drastic reduction in larval occurrence and densities: larvae were only reported at 8 stations with maximal densities reaching just 85 larvae $\mathrm{m}^{-2}$ at $\mathrm{Stn} 84$.

Physico-chemical characteristics of the waters showed a clear spatial gradient, with less saline and warmer waters within the Bay of Mont-Saint-Michel than in the open sea (Fig. 6). During the first cruise, water temperatures of $>17.5^{\circ} \mathrm{C}$ and salinities of $<34.8$ were observed within the bay and in a narrow coastal band north of Granville, while temperature was $<17.0^{\circ} \mathrm{C}$ and salinity $>35$ off the Chausey Islands. A similar spatial pattern was reported during the second cruise, but with a bay-wide increase of temperature of about $1^{\circ} \mathrm{C}$. Maximal chl a concentrations were found in the central part of the bay during the 2 cruises, with values reaching 3.00 and $1.50 \mu \mathrm{g} \mathrm{l}^{-1}$, respectively. Larval densities were significantly correlated to temperatures (positively) and salinities (negatively), especially during the first cruise, when densities were the highest (Table 1). Although larval densities were related to chl a concentrations during the first cruise $(R=0.426, p<0.05)$, the relationship was not apparent on the second cruise.
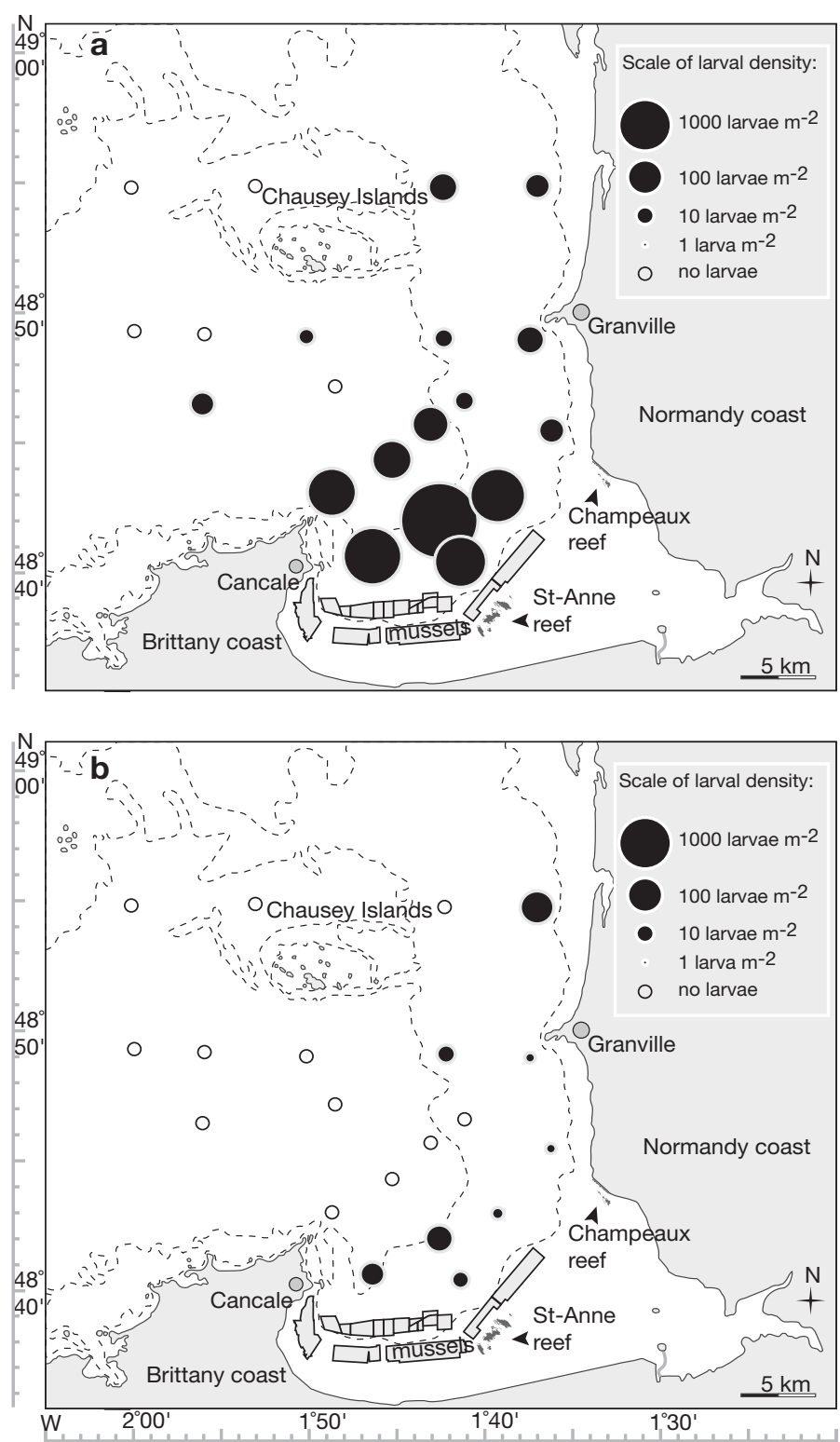

Fig. 5. Sabellaria alveolata. Large-scale distribution of larvae on (a) 15 to 17 and (b) 20 to 22 July 2002 in the Bay of MontSaint-Michel. Diameters of the circles are proportional to the log-transformed abundance data 

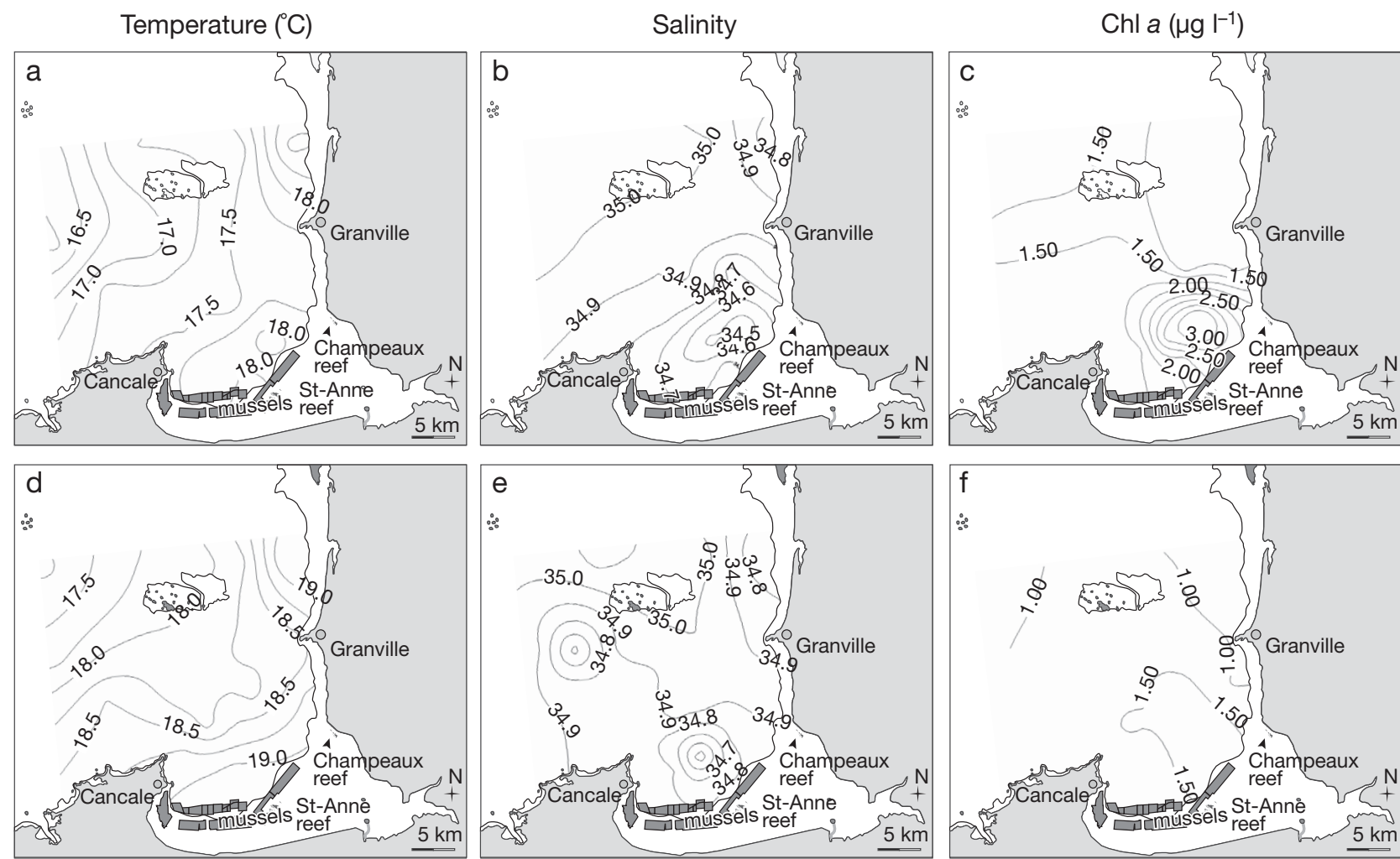

Fig. 6. Large-scale distribution of water column physico-chemical parameters - temperature, salinity and chl a concentration on (a-c) 15 to 17 and (d-f) 20 to 22 July 2002 in the Bay of Mont-Saint Michel. Data represent means for each sampling point

Table 1. Sabellaria alveolata. Spearman's coefficient of rank correlation between larval densities and physico-chemical parameters (temperature, salinity and chl a concentration) for the 2 cruises $\left(\mathrm{N}=20\right.$ for both cruises). ${ }^{*} \mathrm{p}<0.05 ;{ }^{* *} \mathrm{p}<0.01$; ${ }^{* * *} \mathrm{p}<0.001$; ns: not significant

\begin{tabular}{|lrrrr|}
\hline & \multicolumn{2}{c}{ Cruise 1 } & \multicolumn{2}{c|}{ Cruise 2 } \\
& $\mathrm{R}$ & $\mathrm{p}$ & $\mathrm{R}$ & $\mathrm{p}$ \\
\hline Temp. $\left({ }^{\circ} \mathrm{C}\right)$ & 0.727 & $* * *$ & 0.774 & $* *$ \\
Salinity & -0.858 & ${ }^{* * *}$ & -0.505 & $*$ \\
Chl $a\left(\mu \mathrm{g} \mathrm{l}^{-1}\right)$ & 0.426 & $*$ & -0.040 & $\mathrm{~ns}$ \\
\hline
\end{tabular}

\section{Tidal transport and vertical distribution of Sabellaria alveolata larvae}

Results of the $24 \mathrm{~h}$ time series showed that shortterm variations of larval concentration depended on the stage of the tide (Fig. 7): there was an increase in larval abundances in the samples taken toward the end of ebb tide and, conversely, a decrease in the samples taken toward the end of the flood. The 2 tidal cycles showed a similar temporal pattern in larval abundances, but with a 10-fold lower abundance during the second low tide (maximal abundances of 331 and 32 larvae $\mathrm{m}^{-3}$, respectively). Characteristics of the water column (temperature, salinity, chl a) are given in Fig. 8. The water column was well mixed and there was no clear stratification, except in the first metre for salinity. Waters were colder and more saline at high tide $\left(18^{\circ} \mathrm{C}\right.$ and 34.9$)$ than at low tide $\left(19^{\circ} \mathrm{C}\right.$ and 34.7$)$. Chl a concentrations ranged from 2.0 to $1.0 \mu \mathrm{g} \mathrm{l}^{-1}$.

A change in the centre of mass of Sabellaria alveolata larval distribution was observed in relation to the tidal cycle as it moved toward the surface $(\mathrm{RZCM}=0)$ during flood tide and rapidly went deeper, toward the middle or the bottom (RZCM $=0.6$ or 0.7 ), during ebb tide (Fig. 8). At the same time, the evolution of the CV exhibited strong changes and did not seem to vary with RZCM, since no correlation was observed between RZCM and CV $\left(p>0.05, r^{2}=0.14\right)$. The highest CV values were measured at low and high tide (i.e. when water currents were the lowest), except during the night. This suggested that larvae were able to aggregate close to the surface at high tide and were deeper at low tide. Moreover, a 1-way Kruskall-Wallis test showed no significant changes in relative vertical distribution between each larval stage $(p=0.093)$, showing that movement of the larvae in the water column cannot be attributed to one particular stage. 


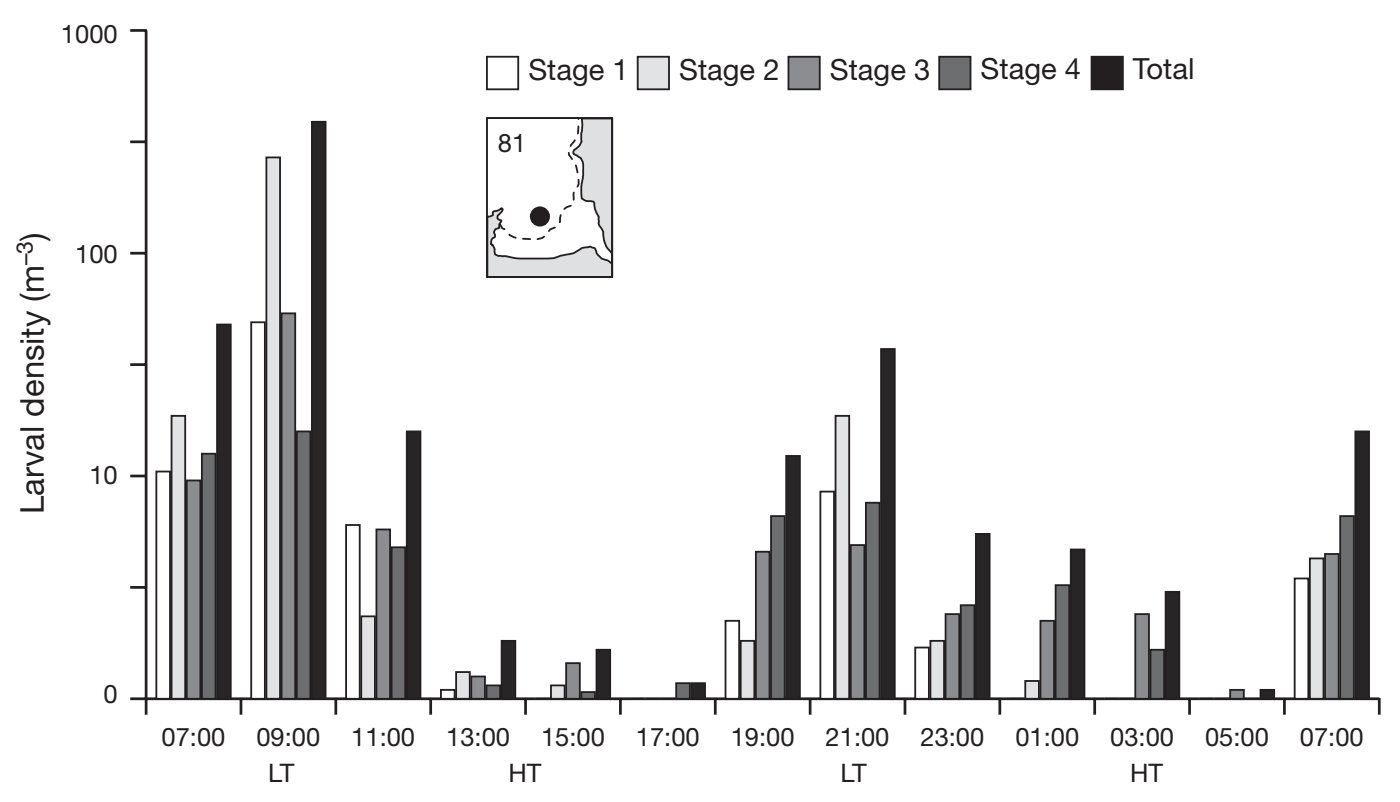

Fig. 7. Sabellaria alveolata. Short-term variations of larval densities observed during a $24 \mathrm{~h}$ time series at Stn 81 in the Bay of Mont-Saint-Michel (18 to 19 July 2002). All larval stage densities (log transformed) are detailed, as well as total abundance. Horizontal bar indicates night hours. LT: low tide; HT: high tide
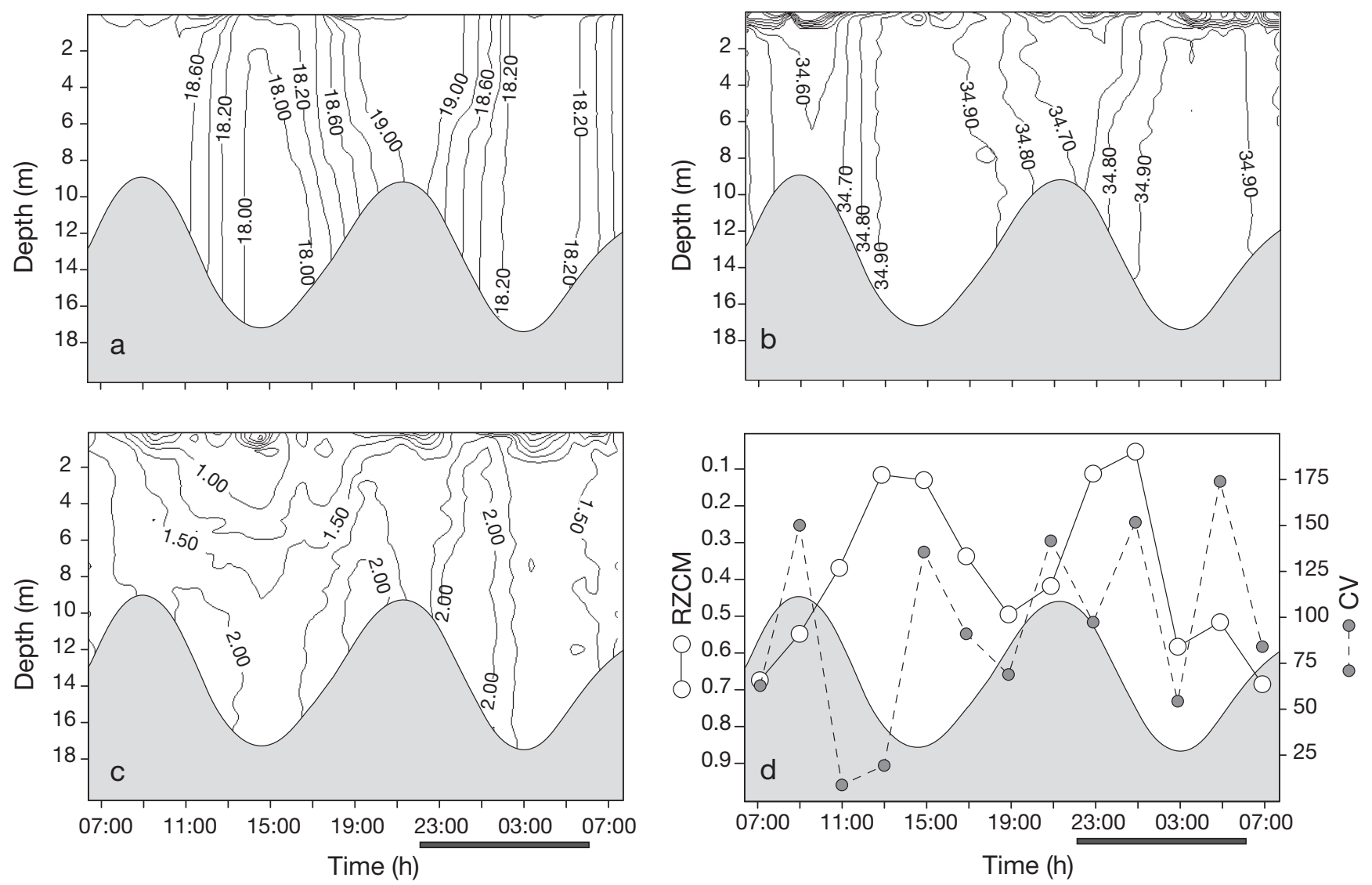

Fig. 8. Sabellaria alveolata. Short-term variations of (a) temperature $\left({ }^{\circ} \mathrm{C}\right)$, (b) salinity, (c) chl a concentration $\left(\mu \mathrm{g} \mathrm{l}^{-1}\right)$, and $(\mathrm{d})$ larval relative centre of mass (RZCM) during a $24 \mathrm{~h}$ time series at Stn 81 in the Bay of Mont-Saint-Michel (18 to 19 July 2002$)$. 


\section{DISCUSSION}

\section{Occurrence of Sabellaria alveolata larvae, estimation of planktonic lifetime and mortality}

Sabellaria alveolata has a protracted spawning season, as suggested by the presence of larvae, including the trochophore stage, during a large part of the year. Semi-continuous spawning probably takes place, with 2 main periods, the most important one occurring early in May and the second occurring in early September. These results are in agreement with previous studies on the reproductive biology of $S$. alveolata, which showed that mature adults able to release eggs or sperm are present all year long, with maximum spawning activities from March to September in the Bay of Mont-SaintMichel (Dubois 2003) and in the bay of Bourgneuf, French Atlantic coast (Gruet \& Lassus 1983). Nevertheless, the presence of ripe worms does not necessarily mean that individuals reproduce. Hence, the presence of ripe females in the Bay of Mont-Saint-Michel during February and March 2002 (Dubois 2003) did not correspond with the presence of larvae in the water column. From artificial fertilisations in the laboratory, Gruet (1982) indicated that no successful fertilisation could be obtained from ripe females from October to February. Conversely, in the Bassin d'Arcachon (French Atlantic coast), Cazaux (1970) reported that the highest abundances in S. alveolata larvae were found in winter (from October to March) and that almost no larvae were found during the summer. In North Cornwall (UK), the spawning season seemed to be restricted to July (Wilson 1971). Such geographical variations in the pattern of sexual maturity have been commonly reported among polychaetes, mainly due to environmental factors, such as temperature, photoperiod, or food availability (Bhaud 1972).

An extended period of reproduction and larval occurrence can increase the probability that some larvae match favourable environmental conditions and successfully settle. However, almost no larvae were collected during a seasonal sampling of larvae previously conducted in the Bay of Mont-Saint-Michel in 2001 (S. Dubois pers. obs.), suggesting large year-toyear variations in the reproductive effort of Sabellaria alveolata as reported for other polychaetes (Olive 1984). Through sexual maturity surveys, Gruet (1982) suggested that $S$. alveolata reproduces approximately every 3 yr.

Although estimates of Sabellaria alveolata planktonic lifetime are highly variable, ranging from $6 \mathrm{wk}$ to 9 mo (Cazaux 1964, Wilson 1968a,b, 1970, 1971), our results suggested that planktonic lifetime was between 4 and $10 \mathrm{wk}$. We assumed a first spawning period in early May (2 May 2002), then determined a larval planktonic lifetime of at least $10 \mathrm{wk}$, since Larval Stage 4 -i.e. ready for metamorphosis and settlement - was not sampled before mid-July (15 July 2002). The same calculation applied for the second period of high larval densities, with spawning starting 3 September 2002 and the massive appearance of Larval Stage 4 taking place at the end of September (30 September 2002), provided a reduced larval planktonic lifetime of $4 \mathrm{wk}$. Thus, the planktonic lifetime of $S$. alveolata appeared to be variable throughout the year. Food and temperature are known to strongly influence larval life duration (see Reitzel et al. [2004] for temperature and Qian \& Chia [1991] for food). In the Bay of Mont-SaintMichel, the presence of trochophore larvae at high densities corresponded to the spring and autumn phytoplanktonic blooms, suggesting that food is not a limiting factor. By contrast, the shorter estimates of time to reach metamorphosis in autumn could be related to the higher temperatures (about $8^{\circ} \mathrm{C}$ higher than in spring). Experiments carried out on $S$. vulgaris have demonstrated that larvae grew twice as fast at $23^{\circ} \mathrm{C}$ as they did at $19^{\circ} \mathrm{C}$ (Curtis 1973).

Although larval natural mortality is of primary importance in understanding the role of the larval phase on dispersal capacities and population dynamics (e.g. Ellien et al. 2004), field estimates of larval mortality are rare because of the difficulty in monitoring larval populations. Our time-series sampling allowed us to propose a crude estimation of larval mortality in Sabellaria alveolata. Here, we used total larval abundances at 3 dates $(3,17$ and 30 September-Stn 78), with the first date corresponding to a spawning event of almost all Stage 1 larvae, with mostly Stage 2 larvae at the second date, and Stage 3 and erpochete larvae at the third date. Larval mortality was then calculated, assuming that the same cohort was sampled and that larval immigration/emigration were insignificant, as in Rumrill (1990) with:

$$
m=-\ln \left(N_{t} / N_{0}\right) \times 1 / t
$$

where $N_{0}$ is the initial number of larvae and $N_{t}$ is the number of larvae after $t$ days. Mortality was $0.089 \mathrm{~d}^{-1}$ between 3 and 17 September and $0.097 \mathrm{~d}^{-1}$ between 17 and 30 September. These values are in the range of those reviewed by Rumrill (1990) for 23 species of marine invertebrates $\left(\right.$ mean $=0.229 \mathrm{~d}^{-1} ; \mathrm{SD}=0.228$; range $=0.016$ to 0.820 ) .

\section{Horizontal distribution of Sabellaria alveolata larvae}

The 2 large-scale surveys as well as the time-series stations (Stns 77 to 80 ) showed that larvae were concentrated mainly within the bay and close to the coast. Horizontal distribution at large scale showed that the 
spatial distribution of Sabellaria alveolata larvae was highly patchy. High concentrations of larvae were correlated to waters characterised by a higher temperature and a lower salinity and, to a lesser extent, by a higher phytoplankton biomass. Hydrodynamic patterns are known to greatly affect larval dispersal of marine invertebrates at large scale and account for the relationship between larval distribution and water mass properties (Bradbury \& Snelgrove 2001). In the English Channel, because of shallow waters and irregular topography, instantaneous tidal currents generate long-term currents (i.e. residual tidal currents), which are often 1 or 2 orders of magnitude lower than the instantaneous currents. Although larvae are advected by these instantaneous currents, their net transport over the planktonic lifetime, which is quite longer than the tidal period, can be evaluated by the residual velocity fields (Salomon 1991). Thus, tidal residual currents within the Bay of Mont-Saint-Michel (Garreau 1993) may well explain horizontal distribution and retention of $S$. alveolata larvae with a large and permanent gyre off Cancale, as well as a drift of water masses to the north along the Norman coast. Coastal eddies and gyres generated by cape effects like this off Cancale result in very little net transport and could contribute to the entrapment of larvae for a few weeks within the bay (Ellien et al. 1999, Ménesguen \& Gohin 2006).

Despite the potential role of the gyre off Cancale in larval retention, a strong decrease in larval densities has been observed between the 2 spatial surveys ( 27680 vs. 82 larvae $\mathrm{m}^{-2}$ for maximal densities). Furthermore, a 10-fold fall-off of larval abundances was reported during the $24 \mathrm{~h}$ time series on 18 to 19 July. Several explanations can then be proposed to explain such a pattern:

(1) A massive export of larvae to areas outside the sampling area: this hypothesis seems unrealistic as meteorological conditions between 15 and 22 Julyi.e. north-easterly or north-westerly winds from 4 to $8 \mathrm{~m} \mathrm{~s}^{-1}$ - were insufficient to disrupt the gyre off Cancale and would rather have transported larvae southward within the bay (Salomon \& Breton 1993).

(2) A massive settlement between the 2 surveys: this hypothesis could also be excluded as $80 \%$ of the larvae were not at stages able to settle (Stages 1 to 3$)$.

(3) A mass larval mortality: even if larval patches may have been partly 'diluted' in coastal waters over time such a mass-mortality hypothesis seems most likely. Knowing that mussels could significantly predate zooplankton organisms including polychaete larvae (Davenport et al. 2000, Lehane \& Davenport 2006), such predation could explain the considerable larval wastage during the $24 \mathrm{~h}$ time series.

\section{Tidal transport of Sabellaria alveolata larvae}

The $24 \mathrm{~h}$ study indicated that larval abundances exhibited cyclic variations, with maximal densities occurring around low tide. As mentioned previously from the study on large-scale larval distribution, this pattern confirms that most larvae were present in the warmer and less saline coastal waters and oscillated with tides in the inner Bay of Mont-Saint-Michel. Even if it was argued that the passive oscillation of a larval patch could be sufficient for partial retention of larvae in coastal zones (Levin 1986), Sabellaria alveolata larvae exhibited vertical migration by moving towards the surface during the flood. This pattern of migration, which has been reported for numerous marine animals including polychaete (Curtis 1973), barnacle (De Wolf 1973), crustacean (Cronin 1982) and fish larvae (Rowe \& Epifanio 1994), could significantly alter their dispersal (see review by Gibson 2003). According to the vertical current shear stress, larvae may exhibit net landward transport, migrating up in the water column to faster currents near the surface during flood tide and descending to weaker currents near the bottom during ebb tide. This process known as selective tidal stream transport can promote a preferential larval transport from offshore waters to the coastline. On the other hand, tidal currents can also be used to prevent transport and retain larvae close to the reef location if larvae migrate around the depth of no net motion. Due to the lack of data on the vertical structure of tidal currents, these 2 mechanisms could not be distinguished.

The factors responsible for such a migration are not fully understood, even if some of them have been investigated, such as food (Fortier \& Leggett 1983), salinity (Forward 1989), hydrostatic pressure (Forward et al. 1989, Marsden 1994) and endogenous clock (Duchêne \& Queiroga 2001). In the Bay of Mont-SaintMichel, the lack of a clear physical stratification of the water column suggests that hydrostatic pressure or endogenous rhythms may best explain the vertical distribution of Sabellaria alveolata larvae.

The phenomenon of diel vertical migration occurs widely in many marine zooplankton taxa including invertebrate larvae (Rawlinson et al. 2004). However, Sabellaria alveolata have not been shown to be clearly sensitive to light, although Curtis (1973) reported from culture jars that $S$. vulgaris larvae are photopositive, at least during the first $2 \mathrm{wk}$ of their life, and Thorson (1964) pointed out that the larvae of intertidal invertebrates are usually photopositive during their later stages. Indeed, no difference in vertical distribution was observed between day and night samples, with larvae migrating toward the surface during flood tide in the day as well as at night. In addition, older larvae are not closer to the bottom than other larval stages, as 
demonstrated for some polychaete species (Lagadeuc 1992, Thiébaut et al. 1992) or for other marine invertebrate taxa such as echinoderm larvae (Banse 1986) and crustacean larvae (Bousfield 1955).

\section{Implications in managing Sabellaria alveolata reefs}

The main objectives of the present study were to evaluate the role of the larval phase on the resilience capacity of the Sabellaria alveolata reefs, which are the largest in Europe and are now considered a 'biological inheritance'. These biogenic reefs are suffering from direct (Dubois et al. 2002) and indirect (Dubois et al. 2006) anthropogenic disturbances, and their long-term survival seems to be uncertain. We demonstrated here that $S$. alveolata larvae may benefit from different processes acting at different spatial and temporal scales to promote larval retention. At the large scale, tidal residual current fields (Garreau 1993) could contribute to strong larval retention within the bay and limit horizontal distribution. Moreover, at the local scale, this study showed evidence of vertical tidal migration that contributed to the delivery of larvae to near-shore reef habitats. Larval retention may explain the persistence of $S$. alveolata reefs in the Bay of Mont-Saint-Michel for several 100s of years (Audouin \& Milne-Edwards 1832), through episodic events of massive settlement and probably balanced by the lack of larval supply observed in some periods (e.g. in 2001). Nevertheless, recent development and restructuring of shellfish farming in the bay - i.e. from 2000 to 2004 raise the question of the influence of high concentrations of mussels and oysters close to the Sainte-Anne reef on larval mortality. At the bay scale, such enormous biological filters might contribute substantially to spatial and temporal variations in reef larval supply and threaten the persistence of the reefs. In this case, management measures should guarantee a socially acceptable trade-off between the economic development of shellfish farming and the conservation of the natural biogenic reefs.

Biological data concerning Sabellaria alveolata larvae could now be used in a further step to develop a numerical model of larval dispersal with 2 broad questions: (1) In terms of management strategy, do some reefs receive more larvae than others (source and sink sites)? And (2) Are the 2 reefs connected through movements of larvae by flow, and are supplies of larvae sufficient to allow maintenance of the 2 existing reef sites in the bay?

Acknowledgements. The authors are grateful to the 'Côte d'Aquitaine', the 'Côte de la Manche' and the 'Louis Fage' crews, especially C. Hennache, A. Chenu and P. Félin for their valuable assistance in field sampling. We thank M. Blanchard (IFREMER, Brest) and Y. Lagadeuc (University of
Rennes) for their help in data acquisition. We are most grateful to Dr. F. Viard, Profs. J. Commito and R. Condrey, and 4 anonymous referees for their valuable comments and corrections of the first draft of the manuscript. This study was financed by the French National Programme on Coastal Environment (PNEC) - Site Atelier 'Baie du Mont Saint Michel'. S.D. was supported by a PhD national research grant.

\section{LITERATURE CITED}

Audouin E, Milne-Edwards H (1832) Recherches pour servir à l'histoire naturelle du littoral de la France ou recueil de mémoires sur l'anatomie, la physiologie, la classification et les moeurs des animaux de nos côtes; voyages à Granville, aux Iles Chausey et à Saint-Malo. Crochard édition, Paris

Banse K (1986) Vertical distribution and horizontal transport of planktonic larvae of echinoderms and benthic polychaetes in an open coastal sea. Bull Mar Sci 39:162-175

Bhaud M (1972) Quelques données sur le déterminisme écologique de la reproduction des annélides polychètes. Mar Biol 17:115-136

Bousfield EL (1955) The cirripede Crustacea of the Hudson Strait region, Canadian eastern Arctic. J Fish Res Board Can 12:762-767

Bradbury IR, Snelgrove PVR (2001) Contrasting larval transport in demersal fish and benthic invertebrates: the roles of behaviour and advective processes in determining spatial pattern. Can J Fish Aquat Sci 58:811-823

Cazaux C (1964) Développement larvaire de Sabellaria alveolata (Linné). Bull Inst Oceanogr Monaco 62:1-15

Cazaux C (1970) Recherches sur l'écologie et le développement larvaire des polychètes de la région d'Arcachon. Thèse d'Etat, Université de Bordeaux

Cronin TW (1982) Estuarine retention of larvae of the crab Rhithropanopeus harrisii. Estuar Coast Shelf Sci 15:207-220

Cunningham PN, Hawkins SJ, Jones HD, Burrows MT (1984) The biogeography and ecology of Sabellaria alveolata. Nature Conservancy Council CSD report, No. 535, Peterborough

Curtis LA (1973) Aspects of the life cycle of Sabellaria vulgaris Verrill (Polychaeta: Sabellariidae) in Delaware Bay. PhD thesis, University of Delaware, Newark

Davenport J, Smith RJJ, Packer M (2000) Mussels Mytilus edulis: significant consumers and destroyers of mesozooplankton. Mar Ecol Prog Ser 198:131-137

De Wolf P (1973) Ecological observations on the mechanisms of dispersal of barnacle larvae during planktonic life and settling. Neth J Sea Res 6:1-129

Dubois S (2003) Ecologie des formations récifales à Sabellaria alveolata (L.): valeur fonctionnelle et patrimoniale. $\mathrm{PhD}$ thesis, Muséum National d'Histoire Naturelle de Paris

Dubois S, Retière C, Olivier F (2002) Biodiversity associated with Sabellaria alveolata (Polychaeta: Sabellariidae) reefs: effects of human disturbances. J Mar Biol Assoc UK 82: $817-826$

Dubois S, Barillé L, Retière C (2003) Efficiency of particle retention and clearance rate in the polychaete Sabellaria alveolata L. CR Biol 326:413-421

Dubois S, Commito JA, Olivier F, Retière C (2006) Effects of epibionts on Sabellaria alveolata (L.) biogenic reefs and their associated fauna in the Bay of Mont Saint-Michel. Estuar Coast Shelf Sci 68:635-646

Duchêne JC, Queiroga H (2001) Use of an intelligent CCD camera for the study of endogenous vertical migration rhythms in first zoeae of the crab Carcinus maenas. Mar Biol 139:901-909 
Eckman JE (1996) Closing the larval loop: linking larval ecology to the population dynamics of marine benthic invertebrates. J Exp Mar Biol Ecol 200:207-237

Ellien C, Thiébaut E, Barnay AS, Dauvin JC, Gentil F, Salomon JC (1999) The influence of variability in larval dispersal on the dynamics of a marine metapopulation in the eastern Channel. Oceanol Acta 23:423-442

Ellien C, Thiébaut E, Dumas F, Salomon JC, Nival P (2004) A modelling study of the respective role of hydrodynamic processes and larval mortality on larval dispersal and recruitment of benthic invertebrates: example of Pectinaria koreni (Annelida: Polychaeta) in the Bay of Seine (English Channel). J Plankton Res 26:117-132

Fortier L, Leggett WC (1983) Vertical migration and transport of larval fish in a partially mixed estuary. Can J Fish Aquat Sci 40:1543-1555

Forward RBJ (1989) Behavioural responses of crustacean larvae to rate of salinity change. Biol Bull (Woods Hole) 176: 229-238

Forward RBJ, Wellins CA, Buswell CU (1989) Behavioural responses of larvae of the crab Neopanope sayi to hydrostatic pressure. Mar Ecol Prog Ser 57:277-297

Frontier S (1969) Sur une méthode d'analyse faunistique rapide du zooplancton. J Exp Mar Biol Ecol 3:18-26

Frontier S (1972) Calcul de l'erreur sur un comptage de zooplancton. J Exp Mar Biol Ecol 10:121-132

Garreau P (1993) Hydrodynamics of the North Brittany coast: a synoptic study. Oceanol Acta 16:469-477

Gibson RN (2003) Go with the flow: tidal migration in marine animals. Hydrobiologia 503:153-161

Gruet Y (1982) Recherches sur l'écologie des 'récifs' d'Hermelles édifiés par l'annélide polychète Sabellaria alveolata (Linné). Thèse d'Etat, Université des Sciences et Techniques de Nantes

Gruet Y, Lassus P (1983) Contribution à l'étude de la biologie reproductive d'une population naturelle de l'annélide polychète Sabellaria alveolata (Linné). Ann Inst Océanogr Paris 59:127-140

Holt TJ, Rees EI, Hawkins SJ, Seed R (1998) Biogenic reefs. An overview of dynamic and sensitivity characteristics for conservation management of marine SACs. Scottish Association for Marine Science, UK Marine SACs Project, Liverpool

Kinlan BP, Gaines SD, Lester SE (2005) Propagule dispersal and the scales of marine community process. Divers Distrib 11:139-148

Lagadeuc Y (1992) Répartition verticale des larves de Pectinaria koreni en baie de Seine orientale: influence sur le transport et le recrutement. Oceanol Acta 15:109-118

Lehane C, Davenport J (2006) A 15-month study of zooplankton ingestion by farmed mussels (Mytilus edulis) in Bantry Bay, Southwest Ireland. Estuar Coast Shelf Sci 67:645-652

Levin LA (1986) The influence of tides on larval availability in shallow waters overlaying a mudflat. Bull Mar Sci 39: 224-233

Lorenzen CJ (1966) A method for the continuous measurement of in vivo chlorophyll concentration. Deep-Sea Res $13: 223-227$

Editorial responsibility: Otto Kinne (Editor-in-Chief), Oldendorf/Luhe, Germany
Marsden JR (1994) Vertical movements and distribution ofplanktonic larvae of the serpulid polychaete Spirobranchus polycerus (Schmarda); effects of changes in hydrostatic pressure. J Exp Mar Biol Ecol 176:87-105

Mathieu R (1967) Le banc des Hermelles de la baie du Mont Saint-Michel, bioherme à Annélides. Sédimentologie, structure et genèse. Bull Soc Geol Fr 9:68-78

Ménesguen A, Gohin F (2006) Observation and modelling of natural retention structures in the English Channel. J Mar Syst 63:244-256

Olive PJW (1984) Environmental control of reproduction in Polychaeta. In: Fisher A, Pfannenstiel HD (eds) Polychaete reproduction: progress in comparative reproductive biology. Gustav Fisher Verlag, Stuttgart, p 17-38

Qian PY, Chia FS (1991) Effects of food concentration on larval growth and development of two polychaete worms, Capitella capitata (Fabricius) and Polydora ligni (Webster). Bull Mar Sci 48:477-484

Rawlinson KA, Davenport J, Barnes DKA (2004) Vertical migration strategies with respect to advection and stratification in a semi-enclosed lough: a comparison of meroand holoplankton. Mar Biol 144:935-946

Reitzel AM, Miner BG, McEdward LR (2004) Relationships between spawning date and larval development time for benthic marine invertebrates: a modelling approach. Mar Ecol Prog Ser 280:13-23

Rowe PM, Epifanio CE (1994) Tidal stream transport of weakfish larvae in Delaware Bay, USA. Mar Ecol Prog Ser 110: 105-114

Rumrill SS (1990) Natural mortality of marine invertebrate larvae. Ophelia 32:163-198

Salomon JC (1991) Hydrodynamic action on benthic macrofauna in tidal coastal zones. ICES Mar Sci Symp 192: $15-23$

Salomon JC, Breton M (1993) An atlas of long-term currents in the Channel. Oceanol Acta 16:439-448

Thiébaut E, Dauvin JC, Lagadeuc Y (1992) Transport of Owenia fusiformis larvae (Annelida: Polychaeta) in the Bay of Seine. I. Vertical distribution in relation to water column stratification and ontogenic vertical migration. Mar Ecol Prog Ser 80:29-39

Thorson G (1964) Light as an ecological factor in the dispersal and settlement of larvae of marine bottom invertebrates. Ophelia 1:167-203

Vorberg R (1995) On the decrease of sabellarian reefs along the German North Sea coast. Publ Serv Géol Lux 24:87-93

Wilson DP (1968a) The settlement behaviour of the larvae of Sabellaria alveolata (L.). J Mar Biol Assoc UK 48: $387-435$

Wilson DP (1968b) Some aspects of the development of eggs and larvae of Sabellaria alveolata (L.). J Mar Biol Assoc UK 48:367-386

Wilson DP (1970) Additional observations on larval growth and settlement of Sabellaria alveolata. J Mar Biol Assoc UK 50:1-31

Wilson DP (1971) Sabellaria colonies at Duckpool, North Cornwall, 1961-1970. J Mar Biol Assoc UK 51:509-580

Submitted: December 19, 2006; Accepted: April 13, 2007

Proofs received from author(s): September 12, 2007 